\title{
On the Social Sustainability of Industrial Agriculture Dependent on Migrant Workers. Romanian Workers in Spain's Seasonal Agriculture
}

\author{
Yoan Molinero-Gerbeau ${ }^{1, * \mathbb{C}}$, Ana López-Sala ${ }^{1}$ and Monica Șerban ${ }^{2}$ \\ 1 Institute of Economy, Geography and Demography (IEGD) of the Spanish National Research Council (CSIC), \\ 28037 Madrid, Spain; ana.lsala@cchs.csic.es \\ 2 Research Institute for Quality of Life (ICCV), Romanian Academy, 050711 Bucharest, Romania; monas@iccv.ro \\ * Correspondence: yoan.molinero@cchs.csic.es; Tel.: +34-9-1602-2832
}

Citation: Molinero-Gerbeau, Y.; López-Sala, A.; Șerban, M. On the Social Sustainability of Industrial Agriculture Dependent on Migrant Workers. Romanian Workers in Spain's Seasonal Agriculture. Sustainability 2021, 13, 1062. https://doi.org/10.3390/su13031062

Academic Editor: Apostolos G. Papadopoulos

Received: 18 December 2020

Accepted: 15 January 2021

Published: 20 January 2021

Publisher's Note: MDPI stays neutral with regard to jurisdictional claims in published maps and institutional affiliations.

Copyright: (c) 2021 by the authors. Licensee MDPI, Basel, Switzerland. This article is an open access article distributed under the terms and conditions of the Creative Commons Attribution (CC BY) license (https:/ / creativecommons.org/licenses/by/ $4.0 /)$.

\begin{abstract}
Since the beginning of the 21st century, Romanian migrants have become one of the most significant national groups doing agricultural work in Spain, initially coming via a temporary migration program and later under several different modalities. However, despite their critical importance for the functioning of Europe's largest agro-industry, the study of this long-term circular mobility is still underdeveloped in migration and agriculture literature. Thanks to extensive fieldwork carried out in the provinces of Huelva and Lleida in Spain and in the counties of Teleorman and Buzău in Romania, this paper has two main objectives: first, to identify some of the most common forms of mobility of these migrants; and second, to discuss whether this industrial agriculture, hugely dependent on migrant work, is socially sustainable. The case of Romanian migrants in Spanish agriculture will serve to show how a critical sector for the EU and for the 2030 Agenda for Sustainable Development of the United Nations, operates on an unsustainable model based on precariousness and exploitation.
\end{abstract}

Keywords: social sustainability; seasonal migration; circular migration; industrial agriculture; Huelva; Lleida; Romanian migration; temporary migration programs; Spain

\section{Introduction}

From the middle of the last century, and especially, since the 1990s, the volume of migrant agricultural workers in developed countries has been steadily growing [1]. Economic, social, and demographic factors have influenced this trend. On the one hand, the economic growth experienced by countries such as Spain and Italy, currently the main fruit and vegetable producers in the EU, caused an exodus from the rural areas in those countries, as cities were offering better job opportunities [2]. On the other hand, and linked to this, the rural labor force was aging and not finding a generational replacement in the native population [3]. A third determining factor is that agricultural neoliberalization, together with the technical advances imported from California, produced a process of industrialization of the countryside, converting farms into authentic food production factories, which in turn required a huge amount of labor [4].

Spain has been one of the territories where these processes have had the greatest impact, becoming an international paradigm of the transformations described above. Enclaves such as Almeria, a province famous for having the largest concentration of greenhouse hectares in the world [5] or Huelva, which has become the second largest international producer of strawberries after California [6], are good examples of this.

From the agricultural business community, but also from bodies such as the EU [7], the Spanish production scheme has been praised and pointed out as a model of good practices. These "triumphant" discourses underlined that the technological conversion of enclaves such as Huelva or Lleida not only generated economic dynamism but are an example of 
food sovereignty and of co-development [8] as they would promote the employment of migrant workers lacking labor alternatives in their places of origin.

It is estimated that every year about 7000 workers arrive to Lleida and between 40,000 and 60,000 workers move to Huelva, returning, at the end of the campaigns, to their countries of origin [9]. This migration, which is circular in nature, is mainly made up of workers from the Maghreb and Eastern Europe, notably Romanians, although its composition has varied according to geopolitical and economic factors [7].

Over the past 20 years, the fields of Huelva and Lleida have been supplied with labor through the implementation of a series of temporary migration programs (TMPs from here on) which have been combined with the employment of irregular workers and, more recently, with the activation of "private" programs run by local companies [9]. While employers have always preferred the TMPs, the weight of each of these recruitment channels has changed significantly over time. In the last decade, following the national government's freeze on the TMPs, "private" programs have gained in importance as the only viable alternative for the provision of workers.

We call "private" programs those initiatives that, in the image of the TMPs, were deployed by companies in both enclaves to bring in migrant laborers from the EU to work in the fields. They proliferated when the TMPs were frozen in order to put a brake on hiring of workers from third countries and promote the employment of migrants already residing in the country and natives; in practice, however, this did not happen, leaving the business community without alternatives [9]. Thus, by renewing contact with Romanian workers who had been part of the TMPs before their country entered the EU, each company articulated its own "program", deploying strategies that ranged from placing job advertisements on the Internet, to organizing worker-selection processes at origin or chartering buses to bring in workers. The European framework and the free movement of EU workers allowed employers to organize their own programs privately in order to have a workforce they would otherwise not obtain.

In this article we will focus on this case, with the aim of both identifying some of the strategies deployed by employers in Huelva and Lleida to access this workforce and to discuss whether the industrial agricultural production model based on the circular movement of workers at the European level is socially sustainable.

For this purpose, we aim to study two aspects that have been barely addressed in the academic literature. At an empirical level, very few articles have analyzed this new phase of "private programs" [7,9-11] and no studies have identified the types of mobility they have articulated. At a theoretical level, although numerous studies have been devoted to pointing out how industrial food production in modern agriculture is based on a model that preys on the environment and is maintained on the basis of worker exploitation [12], few have analyzed this context from a social sustainability perspective.

Analyzing industrial agriculture and its migration dependency from the perspective of social sustainability is especially important due to two major events. First of all, the COVID-19 crisis has shown how dependent modern societies are on the agro-food industry that, in turn, largely depends on the yearly mobility of thousands of workers. Second, sustainability has become a central concept in European policies, as it is the guiding principle of the 2030 Agenda of the United Nations which aims at promoting (among other elements) decent work, protecting the environment, and stimulating a social and ecological way of producing and consuming [13]. All these elements intersect at industrial agriculture, giving this sector a central space in the development agenda.

In order to contribute to the open discussions in the above-mentioned fields, the article is structured as follows: the second section contains the methodology then, in the third section we define the case study: formal, state-driven (and then company-driven) Romanian migration to Spain to work in agriculture, providing a detailed analysis of the "post-program" or "privatized" phase, with the aim of categorizing the types of workers and forms of mobility and recruitment used by employers in this period. The fourth section presents the theoretical and discursive framework of our analysis, focusing on discussions 
of social sustainability then, applying this framework, we discuss the agro-industrial production model based on intra-European circular mobility from the perspective of social sustainability. The fifth section presents our conclusions.

\section{Methodology}

The proposed analysis is based on various sources, including a systematic review of legislative documents and reports produced by the actors involved, together with information obtained from three qualitative fieldworks carried out within the framework of the European-funded TEMPER project (Temporary vs. Permanent Migration).

The first qualitative fieldwork was carried out in the Spanish provinces of Huelva and Lleida, during the 2015 campaigns. Researchers spent a month in each enclave carrying out participant observation and in-depth interviews in four localities of Huelva (Lepe, Moguer, Almonte and Palos de la Frontera) and six localities in Lleida (Soses, Alcarrás, Corbins, Térmes, Alcoletge, and Torres de Segre). During this work, 20 in-depth interviews with Romanian migrants doing agricultural work and seven interviews with employers, social workers, trade union staff, and public housing workers in both provinces were carried out.

The second round of qualitative fieldwork took place between November and December 2016, as well as in August 2017, in two selected Romanian localities situated in the counties of Teleorman and Buzău. There, in addition to participant observation, 18 in-depth interviews with workers doing agricultural work (or who had done it in the past) were done.

The interviews with the migrants were all semi structured, sharing a common script and were carried out outside working hours in different places like bars, their places of residence, public spaces (like parks) and, sometimes, also in their workplaces. The script was different for those who were interviewed in the destination country (Spain) than for those who were interviewed in their origin country (Romania). All the in-depth interviews done in Huelva and Lleida were carried out in Spanish, whereas those that took place in Teleorman and Buzău, were done in Romanian.

Interviewees were selected according to a variety of criteria, seeking to make the sample as heterogeneous as possible. The assessed dimensions were gender, age, region of origin, and first year of work in Spain (before and after 2007).

The other in-depth interviews with actors like employers or trade unionists were not structured and were all carried out in the interviewee's workplaces. These interviews were not scheduled and only took place when researchers in the field found the opportunity to meet these actors.

The following results come from the combination of these experiences, however, as the intention of this paper is to carry out a structural and theoretical macro analysis, no direct quotations will be employed.

\section{Romanian Seasonal Migration to Work in Spanish Agriculture}

3.1. Historical Phases of Romanian Migration to Work in Spanish Agriculture

3.1.1. 1990-2002: Roots of a Long-Term Migration

At the beginning of 1990s, Spain and Romania were two almost unconnected European countries, located at opposite ends of the continent. At that time, few could have imagined that, thirty years later, more than 650,000 Romanians would live in Spain, as the secondlargest immigrant community of the country. The history of this migration starts as early as the first years after the fall of the dictatorial regime of Ceausescu in Romania. It evolved slowly during the 1990s but burst into a substantial flow during the 2000s [14]. Primarily economic, Romanian migration to Spain has mainly been developed through wide migration networks [15]. Romanians have inserted themselves into niches of the Spanish economy prone to migrant work: construction, domestic work, agriculture, and tourism [14]. Their presence in agriculture went rather unnoticed until the beginning of the new millennium. It was after 2002, when Romania signed a bilateral agreement with Spain, 
that Romanians became a reference migrant population for Spanish agriculture, especially in the strawberry fields of Huelva.

The bilateral agreement with Romania was just part of a larger process whose goal was to supply workers for highly seasonal agricultural activities. Started at the end of the 1990s, this process led to the implementation of a series of small, regional TMPs recruiting workers in their origin countries [16]. Bilateral agreements were the main instruments used to recruit workers and different European, African, and Latin American countries were targeted by the Spanish government. However, during their first years of life, the Spanish TMPs seemed especially successful in recruiting Central and Eastern Europeans and Moroccans. If one looks at the largest TMP, the Huelvan one, from 2000 to 2008 more than two thirds of the workers recruited abroad came from only two countries: Romania (55\% of total contracts) and Poland (24\%). As this data suggests, from the start, the Spanish TMP system for agriculture was built on intra-European labor mobility, mainly on Polish and Romanian seasonal migration. These countries entered the Spanish recruiting system as third-countries in relation to the EU, but later both became EU members (Poland in 2004 and Romania in 2007). While the Polish and Romanian cases bear some similarities, the biggest difference between them is that Polish workers left Spanish fields as soon as they became European citizens and were gradually replaced by Romanian workers [17]. Even though their country also became an EU member, Romanians have continued to come season after season to work in Spanish agriculture, providing, at least until the COVID-19 crisis, a flexible pool of workers that can be accessed in direct relation with the need of employers, without any restrictions or regulatory intervention by the authorities in the countries of origin or destination. The fact that Romania joined the EU is the key to understanding this situation. This section of the paper is an attempt to unravel the progress of Romanian migration to work in Spanish agriculture through different phases, from the TMPs to recruitment through "private" programs.

\subsubsection{2-2006: Setting Up a Successful Recruitment System in Romania}

The Spanish authorities signed a bilateral agreement with Romania at the beginning of 2002. The system of recruiting implemented then, mainly directing workers to the fields of Huelva and Lleida, was functioning with minor changes until the beginning of 2007, when Romania became an EU member.

If we look at the Huelva TMP during this period, Spanish data show not only a substantial and rapid increase in the number of contracts signed by Romanians (see Figure 1), but also a certain dependence on Romanian labor (see Figure 2).

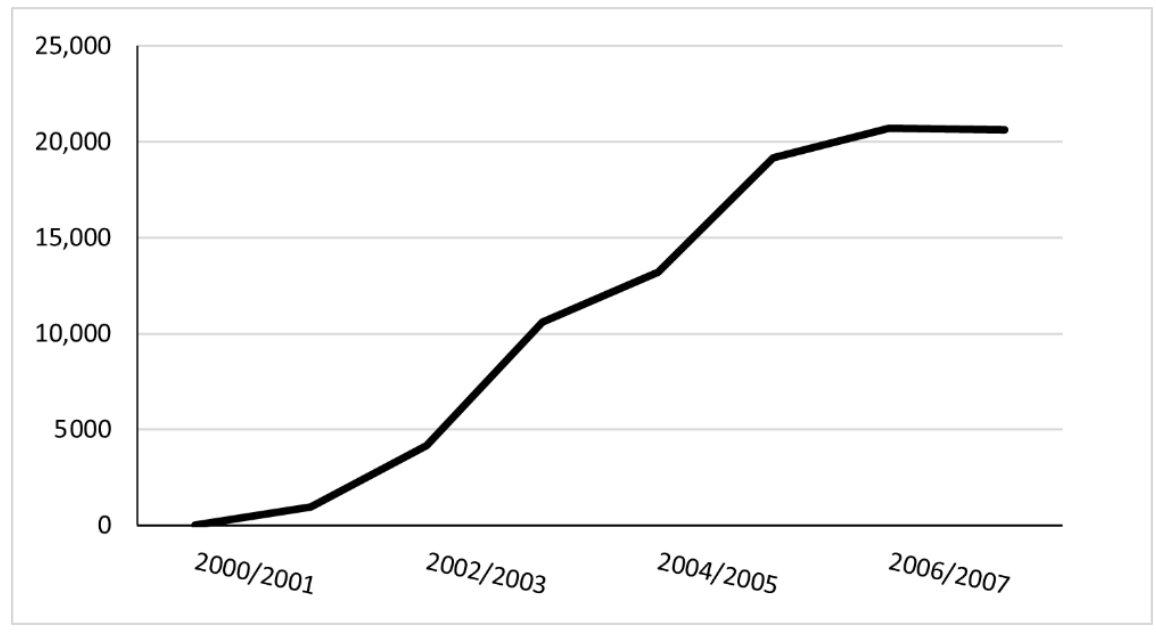

Figure 1. Number of contracts signed by Romanian workers in Huelva, by season, 2000-2008. Source: Macías Llaga et al. (2016: 182). 


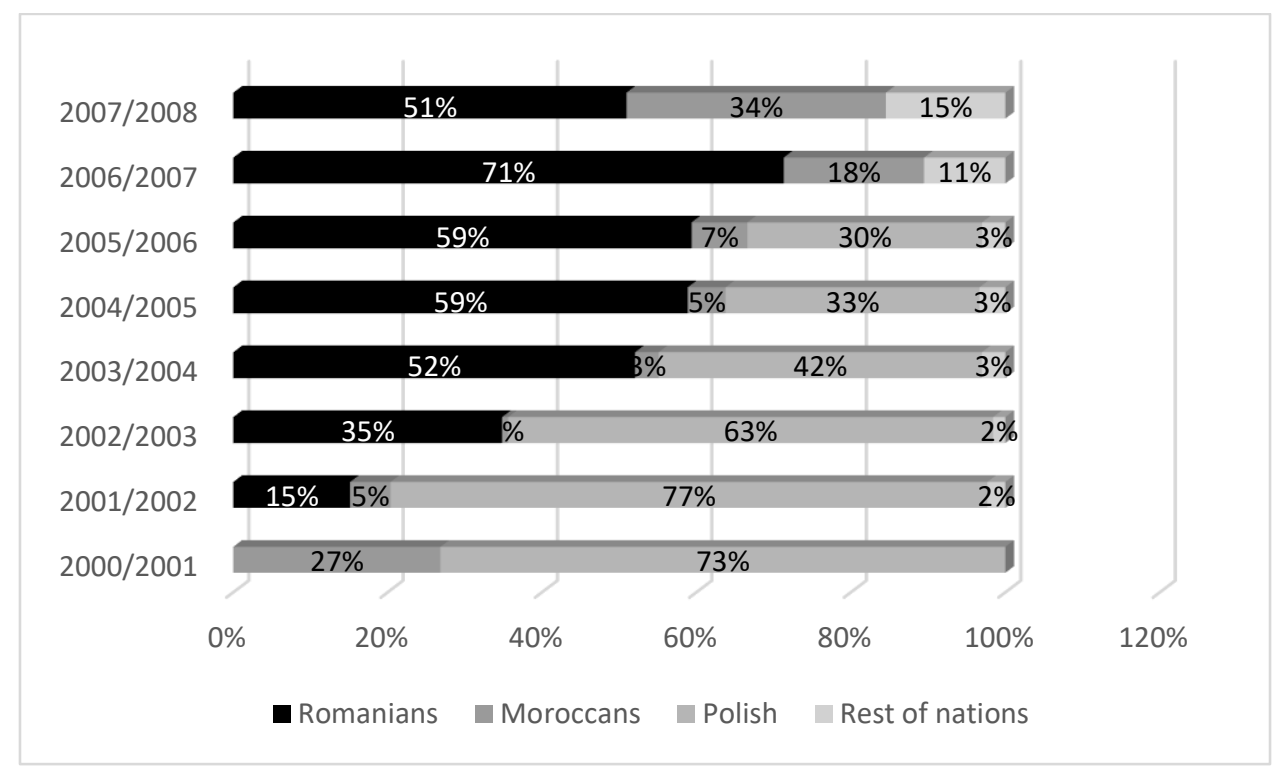

Figure 2. Contracts signed by different nationalities in Huelva, by season, 2000-2008 (\% of total contracts). Source: Macías Llaga et al. (2016: 182).

The rapid success of recruitment in Romania could suggest a highly functional program. In fact, the TMPs benefited from a very favorable context, that, at least partly, explains its rapid extension in Romania.

In 2000, Romania started negotiating its access to the EU in an atmosphere of fear of a (possible) wave of massive migration of Romanians to Europe. 2000-2002, when the agreement was signed, was a period of intense legislative activity and institution building aimed at regulating migration (especially its emigration component) [18]. More importantly, Romania was experiencing a deep economic crisis at the end of 1990s. In particular, the closing of big industrial units related to the communist economy created a pool of young and middle-aged workers with few chances to find local employment [19]. For many of them migration in search of work, which began to increase in the second half of 1990s [14], was the only option available to survive and Spanish agriculture was one of the few routes for a legal and safe migration.

The newly set up Office for Labor Migration Abroad (OLMA, here on) was assigned as the Romanian institutional partner for implementing the bilateral agreement with Spain. OLMA was responsible for organizing the recruiting process in Romania, creating a database of potential workers, organizing the selection process, guiding worker medical checkups, and facilitating, in some cases, departures. Spanish contractors, or their representatives, were directly involved in the selection of workers and their criteria in Romania reflected the interest in finding an obedient, hardworking labor force, strongly motivated to return to their country. Healthy, young, or middle-aged women, with experience working in agriculture, and a family and children in Romania defined the standard profile of a successful Romanian candidate for a temporary contract in Spanish agriculture during TMPs. The whole process was organized in the best interests of Spanish employers, assuring the ready availability of workers without costs, and allowing for subtle mechanisms of extended control of migrants while at destination [7].

It is easy to understand why the Spanish program found, during the first decade of the 2000s, an appropriate work pool in post-communist Romania aspiring to become an EU member, it is not equally straightforward to explain the success of Spanish TMPs in making sure that the seasonal workers returned home at the end of their contracts. Our suggestion here is that this was the result of a combination between the design of the programs and a highly successful selection of workers who "would not stay abroad without a contract". 
The design of the program included many elements that made it difficult for migrants to "escape" during their stay in Spain, while also encouraging them to work until the end of their contracts (e.g., the short duration of the contract increased the opportunity costs of alternatives to completing the contract in its entirety) [2]. Moreover, their return was subjected to remote scrutiny, involving the Spanish Consulate in Romania. However, all these elements are very common among new waves of TMPs around the world [1]. What was different in the case of Romanians was that what Spanish TMPs offered-as a precursory phase of another trajectory of (irregular) migration-was already easily achievable for Romanians: starting in 2002, the same year the bilateral agreement was enacted, Schengen countries withdrew remote control on Romanian mobility through visas, meaning that the first important barrier (entering the destination country) was no longer an issue (as Spain was already a Schengen Area member at that time) [15]. All of this, along with the very specific selection criteria of the employers, produced a typical contract worker not interested in overstaying the contract in Spain or/and lacking resources to integrate in a migration network, which implicitly reduced the tendency to overstay the contract.

Another extremely interesting aspect of this phase, creating the basis for the future development of the "private" programs [10], is the way circularity was shaped within the framework of the TMPs. Even though the Romanian-Spanish bilateral agreement did not openly promote it, how it was implemented encouraged the circularity of workers. Basically, the employers could ask the best workers to return the next season. In this case, migrants signed the contract for a new season at the Spanish Embassy/Consulate, without having to go through the entire selection process again. This was definitely an advantage for the migrant because it eliminated selection costs and the uncertainty related to its result, while also excluding the Romanian authorities from the process (which reduced their capacity to intervene) and, more importantly, built a direct link between employer and the future employees while they are abroad. If one looks at the data provided by Romanian and Spanish sources, the difference in the total number of contracts signed by Romanians is striking (more than 20,000 between 2000 and 2008). One probable reason for this variance has to do with the number of contracts signed by Romanian workers directly with their Spanish employers. The mechanism not only allowed for circularity, but also set up the conditions for further development of a direct relationship between employee and employer, independent of the mediation of Spanish and/or Romanian migration authorities [7].

\subsubsection{7-2013: Complex, Interdependent Transitions}

In 2007, Romania became an EU member. After the experience with the first wave of post-1990 integration (in 2004), most of the Western destination countries chose not to open their labor markets to Romanians. Spain was part of this group, enacting transitional provisions for the first two years. Under these conditions, the previously organized mechanism of recruiting workers in Romania continued. However, an important institutional change was implemented in origin: OLMA, the public body managing recruitment (and the only recruiting agent in relation to Spain) was disbanded. The National Agency for Employment (NAE, here on) took over all its functions related to migration. The most significant difference between the two institutions was that NAE has a network of offices all over the country, which was not the case of OLMA (which since its creation operated only in Bucharest, the capital city). The data publicly available do not allow us to test this assumption, but probably the collaboration with NAE allowed the recruiting process to extend to areas far from the capital city [7].

Only two years later, in 2009, a new change affected recruitment in Romania: Spain decided to drop the transitional measures. Starting from that moment on, Spanish employers could easily and freely sign a contract with any Romanian worker. More importantly, this change appeared when Spanish employers had already been contracting Romanian workers for years, often through direct contact with them. Removing Romanians from potential 
TMPs candidates, as a consequence of their free access to the Spanish labor market, was concomitant of deep changes in the Spanish economy as a whole. The strong effects of the global financial crisis at the end of 2000s and especially the rising unemployment, pushed Spanish authorities to restrain recruitment abroad through TMPs. Under these specific conditions, Romanians became the only viable solution for Spanish employers to secure the workers they needed. The strategies to recruit them diversified, using previous knowledge and contacts to promote the circulation of labor newly applying to Romanians [10]. The perception of our interviewees that nothing has changed for years in their practice of annually working in the Spanish fields confirms this tendency of employers to maintain the model of organizing seasonal migration as promoted by TMPs but under their own private initiatives.

The new arrangement functioned for only two years. In 2011, due to the hard consequences of the global financial crisis, the Spanish authorities revised their decision to drop transitional measures on Romanians and, once again, restrictions were imposed. The measure was successively extended up to the end of the transitory period (January 2014). However, the type of contracting allowed in the case of Romanians was different than for other non-EU nationalities: Spanish employers had to request a labor permit for Romanians, but unlike for third country nationals, no labor market test and no cap were imposed to grant these permits so, in reality, this was a way to prevent Romanians coming without a contract, but not a limitation for their recruitment. In fact, these restrictions practically did not affect their employment in agriculture through private company programs.

\subsubsection{4-Present: Romanian Migrants on Their Own in Spanish Agriculture and Intra-EU Competition for Cheap Labor}

Starting in 2014, the Romanian presence in Spanish agriculture seems to be a matter of the individual choice of the migrants and their employers as between 2009 and 2011. The system of recruitment is still in place, bringing an unknown number of workers to Spanish fields every year. The fundamental change is that there are no controls associated with migrant movement. This unseen army of foreign workers, disciplined for years to circulate in accordance with their employers' needs, flexibly answers the changing needs in Spanish agriculture. Until 2016, when the TMP with Morocco still provided a residual number of workers (around 2000 per year), Romanians constituted the largest contingent of laborers, as no alternative sources for obtaining labor were available for employers. However, in 2016, Spain reactivated the program with Morocco, that progressively increased until reaching about 20,000 workers in the campaigns of 2018 and 2019 [9]. The increasing employment of Moroccans implied a direct decrease in the employment of Romanians, showing that employers consider this country as a flexible solution but not as a first choice.

The Romanian case is interesting for Spanish agricultural employers because the free mobility of these citizens implies that any closure of the TMP can be circumvented employing an increased number of these workers. However, for employers, their free mobility is a problem compared to the restrictive nature of the TMP. Romanians can leave their jobs whenever they want whereas TMP workers cannot do the same, as their presence in Spain is strictly limited to the specific job for which they were recruited. This workforce is thus more stable, and its behavior is more predictable, which makes TMP workers the first option of Spanish agricultural firms [10].

Locking down countries within their borders, the COVID-19 crisis has prompted a process of disentanglement of the complex system of intra-EU circulation for work in agriculture. The new closure of the Spanish TMP (this time by Morocco) has implied a new need for recruiting Romanian workers, shedding light on the dependence of European agriculture on the highly mobile citizens of the continent. An important difference with the previous periods has been that now, several EU countries needed these workers, recasting them as a precious resource, provoking a real competition between EU countries to attract them, which has created new problems (in an already difficult situation) for Spanish producers who have relied on their flexible employment for years. 


\subsection{A Post-Program Period. Exploring the "Privatized" Phase in the Enclaves of Huelva and} Lleida: New Recruitment Practices and Forms of Mobility

The implementation of the TMPs in Huelva and Lleida has played a pivotal role not only in the provision of workers for the agricultural sector in these two provinces, but also in the articulation of forms of seasonal/temporary mobility of Romanian migrants that have been maintained over the time. After more than a decade of implementation of these programs through agreements with different countries [20] the economic crisis broke their continuity and scope, at least temporarily. The severe employment crisis brought about by the recession led the national government, the regulator of these programs, to change its policy and increase efforts to channel local workers, both nationals and unemployed foreign residents, into agriculture in these localities. The direct effect of this new vision, which was the object of some discontent in the business sector, was programs continued to operate, but with a marginal weight compared to other mechanisms of provision and recruitment of workers for these agricultural enclaves [17,21].

In this new scenario, the possibility of recruiting workers from Romania for the Spanish agricultural sector was consolidated as a way to complement the incorporation of local workers affected by the crisis in other economic sectors and thereby maintain the labor force needed for the sector. The new legal status of Romanian workers as citizens of the European Union, which entailed the freedom of movement for workers, allowed employers to avoid the constrictions of immigration legislation. Additionally, in some of the interviews conducted, employers described Romanians as "good workers", who have the skills required by the sector and the ability to cope with the harsh conditions in the fields. In addition, the prior participation of Romanian workers in the programs and their temporary residence in Spain had enabled them to establish and consolidate links with employers and local and foreign workers, which facilitated the activation of these networks in the process of adjusting labor demand and supply in this freely regulated scenario.

In this new phase, characterized by the "absence" of the State from the process, a series of private $[9,10]$ or autonomous initiatives were implemented, adopted exclusively by the business sector, and aimed at workers coming from Romania where the experience they had gained during the previous phase was fundamental. The implementation of these initiatives has been shaped in various ways. In the larger companies and cooperatives, which had previously participated in the programs, the human resources and administration departments adapted to this new situation and developed complete mechanisms for recruiting, managing, and facilitating the movement of workers from Romania. This included personnel selection processes, management of permits and even supervision and organization of travel/transfers. These tasks were carried out either autonomously or in collaboration with the business organizations of both areas which also had a wide experience due to their role during the implementation phase of these programs. Recruitment was mainly based on contact with workers who had previously worked in these companies-within the TMPs-and who became a source of additional contacts and hiring through relationships of trust. This proactive role of the companies and the previous experience of many workers in the sector and their contacts with employers and workers in cooperatives [22] has facilitated their annual displacement during the harvest period in this new phase, maintaining this repeated and cyclical circular migration even in the absence of programs.

These autonomous or private programs of the companies have been combined and supplemented with other recruitment mechanisms. For example, an increasing number of growers have started to recruit workers using informal intermediaries known as "gang employers" (empresarios de cuadrillas in Spanish). These are co-nationals of the workers with previous experience in the sector and personal networks that provide workers for the growers if needed. This strategy of the growers allows them to adapt to the changing needs for labor in an uncertain context of production subject to weather conditions and changes in the schedule of the demand. In some of the interviews conducted, it was indicated that this type of informal intermediation has increased the insecurity of the workers and 
that many have had bad experiences with these intermediaries who collect a significant commission or monthly part of their wages; they also reported delays in the formalization of contracts or receiving contracts of shorter duration or fewer hours than initially agreed upon during the recruitment process. Finally, in the last five years, a trend observed in other Spanish agricultural areas has been consolidated, namely the constant increase and consolidation of the participation of temporary employment agencies (TEAs) in this sector in the analyzed locations [22].

The circular migration promoted by the programs in Huelva and Lleida that was maintained during the last decade has been combined with other forms of labor mobility in the case of the Romanian population. Thus, one of the trajectories identified in our interviews was the transit from seasonal circular migrants to permanent workers or longterm temporary circular workers.

Some workers involved in past seasonal schemes became permanent residents and now live in Huelva and Lleida year round. This trajectory was detected in male and female long-term agriculture workers who have some personal or formal skills that allowed them to improve their work status (proficiency in Spanish, specialized agriculture skills, etc). Most of them started working in the fields as hand workers but over the years they were promoted to "better" positions in the production process. Most of the immigrants interviewed that became permanent residents (and kept working in the agriculture sector) today work in supervisory roles as forepersons (capataces in Spanish) and are in charge of groups of co-nationals, managing and controlling work and packaging in the fields. Their tasks also include training new workers, listing, supervision of the accommodations, quality control, translation, assistance in contact with social and health public services and contact between growers, agriculture company staff and the workers, etc. Their work is concentrated during the harvest period, but they are also involved in other tasks related to the management and planning of the work for the next season. Some of them also combine these tasks working in packaging and storage in the warehouses and in some transformation activities within the same company.

In other cases, they work for 8-9 months a year in Spain and return to Romania for 3-4 months a year during the winter period. They have what are called in the Spanish labor legislation "indefinite-discontinuous contracts" (contratos fijos-discontinuos in Spanish), a type of contract quite common in seasonal sectors, such as hospitality. In practice, it implies forms of circular mobility over the year but a legal "permanent stay" in Spain. In this sense we can label this category of workers with indefinite discontinuous contracts as "long-term temporary circular workers".

In general, these two categories of workers have very positive views of their migration experience and they consider their long-term contracts an improvement on what short-term seasonal workers receive (involved or not in schemes). The legal and labor stability of this profile of agriculture workers have allowed them to save money and invest in property, especially houses and land lots in Romania. One important aim for all of them is to invest in the formal education of their children.

Finally, we identified another category in our fieldwork: permanent Romanian immigrants working seasonally in the agriculture sector. During the first years of the last decade agriculture became a "refuge sector" [23] for permanent immigrants in Spain. Working in the agriculture sector became a new strategy to remain in the formal labor market and to maintain their legal status. This trend can be seen in different regions of Spain where agriculture is an important sector, as has been noted in other studies [24]. In this sense, permanent immigrant residents are now seasonally working in agriculture as a consequence of the poor employment opportunities in other sectors. This change is well described by interviewees. In this category we can appreciate different work itineraries. For a significant part of these immigrants who have resided for years in Spain, agriculture was the first sector where they could work, formally and informally, during their first years in Spain. Agriculture was a sector with a high demand for workers and offered them a way to access to a legal status and increase their income. During the economic 
boom years, job opportunities in other sectors, such as construction and hospitality, let them improve their professional and social conditions and leave a sector that is not so attractive in terms of salaries, status and working conditions [16]. However, the economic crisis forced them to return to the sector. In most cases they combined seasonal work in agriculture with other formal or informal jobs in construction, domestic work, etc. as a survival strategy to keep their legal status and earnings. This type of worker manifests the highest degree of frustration and considers returning to the agriculture sector as a failure in their migration project and their social promotion in Spain. In some cases, they combine their work in Spain with some seasonal activities in other European countries to complete their annual income or link seasonal work periods in different provinces and crops. In this way they provide temporary labor for the intranational or intraEuropean agriculture circuits. Workers interviewed also mentioned that they are combining their seasonal work in Spain with other seasonal or temporary jobs in Romania, presenting a pattern of transnational living between two or more countries.

The whole complex involving the temporary migration of Romanians to work in Spain's industrial agriculture reveals a sector that is highly dependent on mobilizing thousands of European workers every year under several (precarious) modalities. These categories show that there is no single model, but a variety of ways to channel these workers to Spanish fields, as no alternative labor sources exist.

In the next sections we will analyze if this model, which is key for sustaining the largest agro-industrial complex of the EU, [1] is socially sustainable. This is not a minor debate because the 2030 agenda of the United Nations, endorsed by the EU, situates sustainable development as a core objective for the next decade. Among its aims, this agenda seeks to promote "responsible" production and consumption systems, as well to protect the environment and reduce inequalities in European societies [13]. Because agriculture is a central sector where all these dimensions intersect, it is key to attaining the Sustainable Development Goals (SDG).

\section{Agriculture, Intra-European Mobility and Social Sustainability \\ 4.1. The Concept of Social Sustainability}

The concept of "social sustainability" is complex because it does not have a clear definition [25] and there is also no common system for measuring it [26]. It is a vaguely used term, to which each author has attributed a series of characteristics that fit their argument, but which are often not theoretically sustained in other scenarios. In addition, its interdisciplinary nature has led to the use of this concept in diverse fields such as urban planning, environmental studies, or sociology, where its application has adopted completely different meanings [27]. Therefore, as Littig and Griessler [28] (p. 70) point out, "this makes sustainability quite a challenge for the social sciences".

In part, the lack of concreteness regarding its content and limits may also be due to its relatively recent nature, since the debate on sustainability only dates back to 1987, when the Bruntland Commission of the United Nations committed itself to promoting "sustainable growth", although the social dimension of this was not discussed extensively until the end of the 1990s [25].

The Bruntland report was a milestone in several fields as it pointed out that capitalism could not be based on an infinite growth that did not take into account the biophysical limits of the planet. At the same time, it stressed that full development can only be achieved with social justice, and, therefore it linked the economy with areas such as environmental studies and sociology [29]. In the end, the perspective of social sustainability broke with what Jason Moore [30] called "Cartesian dualism".

Cartesian dualism is an enlightened supposition that, according to Moore, has permeated the social sciences from the 18th century to the present day, and is based on the assumption that "the natural" or "nature" is an exogenous field to human life, which, in turn, is considered as "civilizing". According to this vision, the two would not only be diametrically separate fields, but the construction of nature as the "wild" opposed 
to the "logos" of human life served to place it hierarchically in a subordinate position. The practical applications of this fracture are immense because it is a dominant vision that for centuries has allowed the submission of the countryside to the city, the contempt of the rural by the urban world and, in economic terms, the capitalist appropriation of nature [31]. The most evident contemporary effect of these processes is climate change, but the emptying of rural spaces and demographic concentration in mega cities are clear products of the subjugation or even the contempt for the value of nature in the prevailing productive model.

The perspective of social sustainability starts from these premises, pointing out that human life and nature are intertwined, and highlighting that it is a mistake to think that a system can be sustainable if it does not consider both dimensions. This means that development objectives as well as the reproduction of human life itself depend on the articulation of an economic system that has to seek the eradication of inequality and to not depredate the environment [29].

Social sustainability thus stands as a framework that aims to indicate which socioeconomic behaviors can be sustained and which can generate long-term problems, despite generating short-term benefits. Therefore, it is not positioned within the developmentalism debate, that is, the construction of a capitalism that aims to reduce poverty and respect the environment [32] or within anti-capitalist positions, such as those defended by political ecology [33] or the world-ecology paradigm [30]. Social sustainability is intended to act as a scientific questioning of the prevailing model, not with the aim of proposing alternative models or pointing out reformist paths, but instead trying to show which elements produce inequality and poverty or which consume resources above the planetary replacement rate. Identifying these problems can lead to public policy proposals or systemic discussions, which in any case already transcend a framework aimed at pointing out paths that are unsustainable in the long term [25].

In this article we do not intend to provide a definition or further characterization of the concept of social sustainability but will start from the premises set out above (that are commonly accepted by the experts working within this framework) to determine to what extent the current Spanish industrial/seasonal agricultural production model is socially sustainable. The case of Romanian migration to Spanish agriculture in Huelva and Lleida serves as a perfect case study for this.

Although certain research in this field has characterized this production model as "unsustainable" [6] and has added some keys to the debate on social sustainability [34] there is still a huge gap in the literature on industrial agriculture, intra-European mobility, and social sustainability.

Much has been said about the precarious working conditions of migrants, whose exploitation is a key factor in keeping food prices low and, thus, competitive [23]. Numerous studies have also pointed to the depredation of natural resources that this type of production entails in the environments where it is established [35]. However, this context, which has been long questioned [12], has not been studied in terms of its present and future sustainability.

To this end, in the following section, we try to determine the social sustainability of the Spanish industrial agricultural production model by applying the conceptual framework proposed by Eizenberg and Jabareen [26]. We have chosen this framework because it provides a comprehensive proposal that considers both physical and non-physical aspects, combining environmental, economic, and social dimensions in a single perspective seeking to avoid proposals that are "undefined, inapplicable and utopian, thus impossible to fulfil, control and facilitate" [26] (p. 4).

In the following section we analyze the case study that underpins this article from the dimensions proposed by these authors to measure social sustainability: risk, equity, security, urban sustainability and eco-prosumption. 


\subsection{Is the Migration-Based Industrial Production Model Socially Sustainable?}

The first of the categories proposed by Eizenberg and Jabareen [26] in their conceptual framework of social sustainability is "risk". Based on the works of Beck, Giddens, and Lash [36] as well as Jabareen himself [37], both authors consider this to be a fundamental dimension of sustainability. Modern societies face numerous risks, with climate change being one of the main threats in social, spatial, structural, and physical terms. Thus, for a social dynamic to be socially sustainable, it must minimize risks, reducing uncertainties and contributing to "address major social issues to cope with the risks of climate change and environmental hazards" [26] (p. 6).

As mentioned above, autonomous/private circular migrations for agricultural work are directly dependent on production factors: it is the needs of the industrial model that drive the constant movement of large numbers of foreign laborers [23]. Therefore, at an initial stage in the analysis of this models' sustainability, it is appropriate to refer to the techniques used by the agriculture industry itself.

Numerous studies have shown that industrial agriculture is harmful to the environment for various reasons. On the one hand, as pointed out by Houser and Stuart [38] (p. 217) "agriculture emits carbon dioxide, methane, and nitrous oxide, accounting for $10-15 \%$ of global anthropogenic greenhouse gas (GHG) emissions and is the sector with the largest contribution to non-carbon dioxide emissions", which, in turn, worsens the conditions for continuing to produce. This is a highly pernicious model for following generations [39].

This model not only pollutes soil and rivers, but also depletes water resources, contributing to desertification and the reduction of biomass and biodiversity [40]. Industrial agriculture devastates the environment where it is implanted, in addition to contributing decisively to climate change. From this point of view, we already have an indication that this is an unsustainable model, to which we can add the carbon footprint left by the transportation of migrants in their annual journeys.

Defenders of this model argue that its positive aspects should not be overlooked, stressing that it allows for the mass production of food, which serves to reduce hunger and guarantees the EU's food sovereignty [41]. However, it is not possible to speak of sovereignty when a central link in the agro-food chain, such as labor, is made up mainly of the annual movement of workers from other States (and therefore subject to economic upheavals, changes in migration laws, etc.) in several modalities, including the ones described in the previous section.

In short, the production model of industrial agriculture in Spain based on the circular migration of foreign workers is highly risky and, therefore, unsustainable according to this dimension.

The second element to determine social sustainability following the Eizenberg and Jabareen model is "equity" [26]. For these authors, no dynamic can be socially sustainable unless it "emphasizes social and economic justice, fairness in pursuing sustainability policies and development" [26] (p. 6). To do so, it must comply with three dimensions: be redistributive, recognize the voices of the most vulnerable actors, and be participatory.

As for the redistributive dimension, according to these same authors, it includes "various rights, such as the right to energy, the right to adequate standards of living, and the right to clean air, water, and related resources" [26] (p. 6). Here, to analyze this point, we can differentiate between the local population living in agricultural enclaves and migrant workers who circulate some parts of the year.

It can be argued that the agricultural sector generates multiple social benefits by creating jobs, financing institutions through the taxes collected and contributing to social welfare in general [42]. Although part of this message may be real, intensive agricultural production areas are generally among the most disadvantaged in Spain, so the agricultural economy, despite its millionaire income, is far from being a factor of development.

If we look at the conditions of migrants working in the sector, there are no possible nuances: there is a complete lack of redistribution. Not only does agricultural work provide 
a very low income that prevents those who set out a circular migration from significantly improving their living conditions at origin, as is the case with Romanian workers [7], but numerous reports and research studies have also pointed out the low standard conditions in which these workers tend to reside during the campaigns. Slums, lack of access to electricity and drinking water, as well as social isolation from big cities, characterize the housing conditions of a majority of these workers [4,12].

With regard to acknowledging the voices of the most vulnerable, again it is worth noting a complete absence of these voices in the decision-making processes affecting agricultural work. As López-Sala [16] points out, during the period of TMPs, worker quotas were decided only by governments, trade unions, and employer associations. In the later phase of the private programs, the first two disappeared from the equation, leaving recruitment exclusively in the hands of each company. As a consequence, migrant agricultural workers have been often described as "invisible" [43], as there has been a complete absence of initiatives where this group could participate in decisive decisionmaking processes. On the other hand, circular migration itself implies that the presence of these workers in agricultural enclaves is limited to a few months a year, which prevents them from settling and organizing stronger collectives [44].

This aspect is linked to the third, that of "participation". Eizenberg and Jabareen [26] think that ensuring the equal participation of actors is essential to consider a social fact "equitable", however, the reality is that migrants are not recognized as valid interlocutors, which prevents them from participating. Moreover, these authors point out that real participation requires guaranteeing legal equity between actors, something that migration laws impede by establishing different legal status for nationals and foreigners.

Therefore, once again it can therefore be deduced that the production and migration model promoted by Spanish industrial agriculture is far from achieving minimum standards of social sustainability.

Thirdly, the Eizenberg and Jabareen model [26] proposes "security" as a central element for defining social facts as socially sustainable. These authors understand this dimension as the need for any initiative to guarantee a safe life for people in vulnerable situations. This would involve reducing gaps such as poverty or neighborhood segregation in order to promote a redistribution of income and more sustainable urban planning.

In the case of circular migrants in Spanish agriculture, these elements are not considered by any of the actors involved, and their reality can be characterized as extremely insecure. In terms of housing, as mentioned above, their temporary presence, together with both low incomes and their willingness to spend as little as possible to save money for their return, often leads migrants to reside in abandoned infrastructures such as factories or old abandoned country houses. In other cases, shantytowns have been created, which are extremely vulnerable to climate change, not only because of the lack of running water and electricity but also because of their exposure to fires resulting from the accumulation of flammable materials, such as plastics [45]. Town councils have tended to ignore these situations, which have been occurring for decades in rural enclaves in Spain, although it would be unfair not to mention that some municipalities have implemented public housing policies for seasonal workers, as in the case of Lleida, although these have also been criticized for their extreme austerity [46].

In short, there are no comprehensive policies for the accommodation of seasonal workers, which means they have what Avallone [47] (p. 104) describes as "an extremely precarious subaltern spatial experience". Furthermore, the low wages of migrant workers and the lack of access to social benefits, means that this dimension cannot be described as socially sustainable.

The fourth element of the Eizenberg and Jabareen [26] model concerns the implementation of sustainable urban planning. For the authors, it is fundamental that all social dynamics promote the constitution of sustainable urban spaces, as these affect both human life and ecosystems. To this end, they insist on various elements that should be promoted: connectivity, installing non-polluting transportation, promoting green spaces, reducing 
the population density of living spaces, etc. We will not go too far in characterizing this dimension as it has been previously shown how residential enclaves for seasonal workers are far from these standards.

There are, however, two determining dimensions. The first is transportation: many seasonal workers settle in slums near workplaces so that they can walk to their workplaces, but in other cases they must use the services of furgoneteros (van drivers), illegal intermediaries who charge workers to bring them to the farm in crowded vehicles [18,48]. This mode of transportation, besides being illegal and taking advantage of the structural weakness of seasonal workers, is dangerous for the lives of the passengers (as there have been numerous cases of accidents) as well as polluting, which makes it highly unsustainable.

The second dimension has to do with the promotion of "green spaces" which Eizenberg and Jabareen, [26] mention as a necessity for a dynamic to be considered sustainable. In this case, as we are dealing with rural spaces, it should be taken for granted, but the opposite is true. Slums are known for their high level of pollution; for instance, public waste collection services do not pass there, which means that the rubbish is piled up and the waste is not recycled. Thus, ironically, far from protecting and promoting the creation of natural spaces, this type of production destroys and pollutes the countryside.

The fifth and final element that makes up Eizenberg and Jabareen's [26] model is what these authors have called "eco-prosumption". Here they refer to the fact that consumers co-produce value, that is, orienting their consumption of products towards those that are more careful with the environment and labor rights implies producing socially sustainable models. In this case, it is clear that consuming fruits and vegetables produced under this model only feeds back into an unsustainable industry. In Spain, but also in Europe, the bulk of food distribution is carried out through large supermarket chains whose shelves are filled with fruits and vegetables massively produced in industrial agricultural enclaves [49]. Certainly, some research indicates that the consumption habits of the Spanish population, in general, are gradually changing, with the purchase of organic products increasing in recent years [50]. However, there are no indications that organic products, despite being more respectful of the environment, are produced in such a way as to guarantee decent working conditions for laborers.

After applying the model of Eizenberg and Jabareen [26], it can be said that none of the elements characterize the industrial agricultural production based on circular migrations as socially sustainable. In fact, the non-exhaustive characterization presented here shows a model that is antagonistic to sustainability, which points to the urgency of thinking about productive alternatives to promote an agri-food sector that respects both the environment and its workers in line with the aims of the 2030 Agenda.

\section{Conclusions}

Over the past 20 years immigrant workers have played a key role in the Spanish agricultural sector. In the enclaves of Huelva and Lleida the type of the crops and the seasonal character of production require a large volume of workers for 4 to 6 months a year. The fields of Huelva and Lleida have been supplied with labor through the implementation of TMPs which has been combined with the employment of irregular workers and, more recently, with the activation of "private" or autonomous programs of local companies. While employers have always preferred the TMPs, the weight of each of these recruitment channels has changed significantly over time. In the last decade, following the national government's freeze on the TMPs during the first years of the economic crisis, "private" programs have gained in importance as an alternative for the provision of workers. Romanian workers have been decisive in this recruitment and provision system.

As we have described throughout the article, the signing of the bilateral agreement between the two countries in 2002 marks the beginning of seasonal labor migrations of Romanian workers that have been maintained over time, since the creation of previous links between workers and employers during the implementation phase of these programs and, subsequently, the freedom of movement within the European Union, has allowed 
the continuity of the annual hiring. Nowadays Romanians continue to come season after season to work in Spanish agriculture, acting as a flexible pool of workers that can be accessed in direct relation with the need of employers, without the restrictive or regulatory intervention of authorities in the country of origin or destination.

Throughout this article, we have delved into the design and implementation of these private programs developed by the business sector, the recruitment strategies set up by employers and the types of mobility they have articulated, aspects that have so far been little analyzed in the academic literature on labor and agriculture in the Spanish case. This task has made it possible to go deeper into the implementation of new strategies developed by the private sector, beyond the intervention of the governments of the countries of origin and destination. It has also served to highlight the complexity of the mobility dynamics derived from this form of migration regulation. In this sense, our analysis has made it possible to go a little further in the links between agricultural work, regulation, and mobility in the field of migration studies.

This article also interrogates the links between industrial agriculture and migration. In particular it discusses whether this agricultural production model based on the massive circular movement of workers at the European level is socially sustainable, another gap in the Spanish academic literature on migration studies. Applying the conceptual framework proposed by Eizenberg and Jabareen [26] we conclude that the productive model of industrial agriculture in Southern Europe, and in particular the model based on circular migration of workers in Huelva and Lleida, is highly risky, promotes social and economic inequality and injustice, produces insecurity and urban unsustainability and it is far from co-producing value. In sum, it is possible to argue that the production and migration model promoted by Spanish industrial agriculture is far from achieving minimum standards of social sustainability and, thus, needs to be deeply reformed in order to achieve the objectives of the 2030 Agenda of the United Nations. In fact, the non-exhaustive characterization presented in this article shows a model that is antagonistic to sustainability, which points to the urgency of thinking about productive alternatives to promote an agri-food sector that respects both the environment and its workers.

Author Contributions: Conceptualization, Y.M.-G., A.L.-S. and M.S.; methodology, Y.M.-G., A.L.-S. and M.S.; software, Y.M.-G., A.L.-S. and M.Ș.; validation, Y.M.-G., A.L.-S. and M.S,.; formal analysis, Y.M.-G., A.L.-S. and M.S.; investigation, Y.M.-G., A.L.-S. and M.Ș.; resources, Y.M.-G.; data curation, Y.M.-G., A.L.-S. and M.Ș.; writing—original draft preparation, Y.M.-G., A.L.-S. and M.S,.; writingreview and editing, Y.M.-G., A.L.-S. and M.S,; visualization, Y.M.-G., A.L.-S. and M.Ș.; supervision, Y.M.-G., A.L.-S. and M.S.; project administration, Y.M.-G.; funding acquisition, Y.M.-G. All authors have read and agreed to the published version of the manuscript.

Funding: The research leading to these results received funding from the AGRIQUALITY project ("Gobernanza de la calidad en las cadenas globales agroalimentarias. Un análisis comparado de los territorios agro-exportadores en España") funded by the Spanish Ministry of Science and Innovation, the Spanish State Agency of Research (Agencia Estatal de Investigación) and FEDER funds of the European Union (Grant Agreement: CSO2017-85507-P) and TEMPER project ("Temporary versus Permanent Migration"), European Union's Seventh Framework Program (grant agreement no.613468).

Data Availability Statement: No new data were created or analyzed in this study. Data sharing is not applicable to this article.

Acknowledgments: We would like to thank the coordinators of this Special Issue, Apostolos G. Papadopoulos, Stavros Zografakis and Loukia-Maria Fratsea, for their kind invitation to participate.

Conflicts of Interest: The authors declare no conflict of interest. 


\section{References}

1. Molinero Gerbeau, Y. La creciente dependencia de mano de obra migrante para tareas agrícolas en el centro global. Una perspectiva comparada. Estud. Geográficos 2020, 81, 031. [CrossRef]

2. López-Sala, A. Producing temporariness, (re)producing precariousness: Regulation, rights and non-citizenship status of temporary immigrant workers. Arbor 2016, 192, 1-4.

3. Sampedro Gallego, R.; Camarero Rioja, L. Inmigrantes, estrategias familiares y arraigo: Las lecciones de la crisis en las áreas rurales. Migraciones 2016, 40, 3-31. [CrossRef]

4. Avallone, G. El campo neoliberal y su crisis: Agricultura, sociedad local y migraciones en la Europa del Sur. Encruc. Rev. Crítica Cienc. Soc. 2013, 6, 39-55.

5. Aznar Sánchez, J.A.; Belmonte-Ureña, L.J.; Tapia-León, J.J. The Industrial Agriculture: “A Model for Modernization” from Almería. In Seasonal Workers in Mediterranean Agriculture. The Social Costs of Eating Fresh? Gertel, J., Sippel, S.R., Eds.; Routledge: Abingdon, UK, 2014; p. 293.

6. Reigada, A. Family Farms, Migrant Labourers and Regional Imbalance in Global Agri-food Systems: On the Social (Un)sustainability of Intensive Strawberry Production in Huelva (Spain). In Migration and Agriculture Mobility and Change in the Mediterranean Area; Corrado, A., De Castro, C., Perrotta, D., Eds.; Routledge: Abingdon, UK, 2017; pp. 95-110.

7. Şerban, M.; Molinero-Gerbeau, Y.; Deliu, A. Are the Guest- Worker Programmes Still Effective? Insights from Romanian Migration to Spanish Agriculture. In International Labour Migration to Europe's Rural Regions; Rye, J.F., O'Reilly, K., Eds.; Routledge: Abingdon, UK, 2017; pp. 22-36.

8. Macías Llaga, I.; Márquez Domínguez, J.A.; Jurado Almonte, J.M. La contratación en origen de temporeros marroquíes para los campos españoles como experiencia de codesarrollo. Cuad. Geogr. 2016, 55, 173-194.

9. Molinero-Gerbeau, Y. Dos décadas desplazando trabajadores extranjeros al campo español: Una revisión del mecanismo de contratación en origen. Panor. Soc. 2020, 31, 141-153.

10. Molinero Gerbeau, Y. La Privatización de los Programas de Migración Temporal en España como Efecto Poscrisis. In Anuario Cidob de la Inmigración; Arango, J., Mahía, R., Moya, D., Sánchez-Montijano, E., Eds.; Cidob: Barcelona, Spain, 2018; pp. 284-306.

11. Luque-Ribelles, V.; Palacios-Gálvez, M.S.; Morales-Marente, E. How Women Migrants Cope with Their Labour Experience: The Case of Eastern European Women Working on Strawberry Farms in Spain. Psychol. Thought 2018, 11, 174-194. [CrossRef]

12. Corrado, A.; De Castro, C.; Perrotta, D. Migration and Agriculture. Mobility and Change in the Mediterranean Area; Routledge: Abingdon, UK, 2017; p. 346.

13. Alfaro Amieiro, M.; Arias Careaga, S.; Gamba Romero, A. Agenda 2030. Claves Para La Transformación Sostenible; Catarata: Madrid, Spain, 2019; p. 320.

14. Sandu, D. Living Abroad on a Temporary Basis. The Economic Migration of Romanians 1990-2006; Open Society Foundation: Bucharest, Romania, 2006; p. 167.

15. Şerban, M. Dinamica Migraţiei Internaţionale: Un Exerciţiu asupra Migraţiei Româneşti în Spania; Lumen: Iaşi, Romania, $2011 ;$ p. 286.

16. López-Sala, A. Induced circularity for selective workers. The case of seasonal labor mobility schemes in the Spanish agriculture. Arbor 2016, 192, 1-12. [CrossRef]

17. Gualda, E. Migración circular en tiempos de crisis. Mujeres de Europa del Este y africanas en la agricultura de Huelva. Papers 2012, 97, 613-640.

18. Serban, M. Migration policies from origin country perspective in the case of Romania. Testing a definition. J. Commun. Posit. Pract. 2015, XV, 72-93.

19. Kideckel, D. România Postsocialistă. Munca, Trupul și Cultura Clasei Muncitoare; Polirom: Iași, Romania, 2010 ; p. 272.

20. López-Sala, A.; Sánchez-Montijano, E. Contratación en origen de latinoamericanos en España: Un marco flexible de gestión. Rev. CIDOB d' Afers Int. 2014, 106, 193-214.

21. Márquez, J.; Gordo, M.; Morales, A. El Laberinto Jornalero. Evolución Reciente de Extranjeros y Españoles en la Agricultura en Márquez. In Más Allá de la Competencia Agrícola Hispano-Marroquí. La Gestión Colectiva de Contratos en Origen, Márquez, J., Ed.; Universidad de Huelva: Huelva, Spain, 2014; pp. 129-162.

22. Juliá, R.; González, A.; Miranda, X. El empresariado agrícola ante la inmigración: Una mirada retrospectiva en el territorio de Lleida para el período 2005-2015. Rev. Int. Estud. Migr. 2020, 10, 96-127.

23. Molinero Gerbeau, Y.; Avallone, G. Producing Cheap Food and Labour: Migrations and Agriculture in the Capitalistic WorldEcology. Soc. Chang. Rev. 2016, 14, 121-148. [CrossRef]

24. Gadea, E.; Castro, C.; Pedreño, A.; Moraes, N. Jornaleros inmigrantes en la agricultura murciana: Reflexiones sobre la crisis, inmigración y empleo agrícola. Migraciones 2015, 37, 149-169. [CrossRef]

25. Colantonio, A. Social sustainability: A Review and Critique of Traditional versus Emerging Themes and Assessment Methods. In Sue-Mot Conference 2009: Second International Conference on Whole Life Urban Sustainability and Its Assessment; Horner, M., Price, A., Bebbington, J., Rohinton, E., Eds.; Loughborough University: Loughborough, UK, 2009; pp. 865-885.

26. Eizenberg, E.; Jabareen, Y. Social Sustainability: A New Conceptual Framework. Sustainability 2017, 9, 68. [CrossRef]

27. Chen, X.; Frank, K.A.; Dietz, T.; Liu, J. Weak Ties, Labor Migration, and Environmental Impacts: Toward a Sociology of Sustainability. Organ. Environ. 2012, 25, 3-24. [CrossRef]

28. Littig, B.; Griessler, E. Social sustainability: A catchword between political pragmatism and social theory. Int. J. Sustain. Dev. 2005, 8, 65-79. [CrossRef] 
29. Vallance, S.; Perkins, H.C.; Dixon, J.E. What is social sustainability? A clarification of concepts. Geoforum 2011, 42, 342-348. [CrossRef]

30. Moore, J.W. Capitalism in the Web of Life: Ecology and the Accumulation of Capital; Verso: New York, NY, USA, 2015 ; p. 316.

31. Moore, J.W. The End of Cheap Nature. Or How I Learned to Stop Worrying about "The" Environment and Love the Crisis of Capitalism. In Structures of the World Political Economy and the Future of Global Conflict and Cooperation; Suter, C., Chase-Dunn, C., Eds.; LIT Verlag: Berlin, Germany, 2014; pp. 285-314.

32. Bresser-Pereira, L.C. Reflecting on new developmentalism and classical developmentalism. Rev. Keynes. Econ. 2016, 4, 331-352. [CrossRef]

33. Foster, J.B. Ecology Against Capitalism; Monthly Review Press: New York, NY, USA, 2002; p. 160.

34. Reigada, A.; Delgado, M.; Pérez Neira, D.; Soler Montiel, M. La sostenibilidad social de la agricultura intensiva almeriense: Una mirada desde la organización social del trabajo. Ager 2017, 23, 197-222.

35. Pedreño Cánovas, A. De Cadenas, Migrantes y Jornaleros. Los Territorios Rurales en las Cadenas Globales Agroalimentarias; Talasa: Madrid, Spain, 2014; p. 240.

36. Beck, U.; Giddens, A.; Lash, S. Reflexive Modernization: Politics, Tradition, and Aesthetics in Modern Social Order; Stanford University Press: Redwood, CA, USA, 1994; p. 236.

37. Jabareen, Y. The Risk City: Cities Countering Climate Change: Emerging Planning Theories and Practices around the World; Springer: New York, NY, USA, 2015; p. 222.

38. Houser, M.; Stuart, D. An accelerating treadmill and an overlooked contradiction in industrial agriculture: Climate change and nitrogen fertilizer. J. Agrar. Chang. 2020, 20, 215-237. [CrossRef]

39. Lal, R.; Delgado, J.A.; Groffman, P.M.; Millar, N.; Dell, C.; Rotz, A. Management to mitigate and adapt to climate change. J. Soil Water Conserv. 2011, 66, 276-285. [CrossRef]

40. Horrigan, L.; Lawrence, R.S.; Walker, P. How sustainable agriculture can address the environmental and human health harms of industrial agriculture. Environ. Health Perspect. 2002, 110, 445-456. [CrossRef]

41. Patel, R. The Long Green Revolution. J. Peasant Stud. 2013, 40, 1-63. [CrossRef]

42. Márquez Domínguez, J.A. Jornaleros Extranjeros en España. El Contingente Agrícola de Temporada Como Política de Control de los Flujos Migratorios; Universidad de Huelva: Huelva, Spain, 2014; p. 344.

43. Cáritas. La Realidad Invisible de Los Temporeros y Asentamientos de Lleida; Cáritas: Madrid, Spain, 2018 ; p. 42.

44. Vosko, L.F. Blacklisting as a modality of deportability: Mexico's response to circular migrant agricultural workers' pursuit of collective bargaining rights in British Columbia, Canada. J. Ethn. Migr. Stud. 2016, 42, 1371-1387. [CrossRef]

45. Pedreño Cánovas, A. La cuestión jornalera entre dos crisis: Condición inmigrante, desafiliación y riesgo de contagio. Sociol. Del Trab. 2020, 96, 1-15. [CrossRef]

46. Achón, O. Desvagabundizando la mano de obra extranjera en España. Rev. Estud. Soc. 2014, 48, 69-83.

47. Avallone, G. Dimensioni della Fragilità Territoriale. Gli Immigrati nelle Aree Agricole della Piana del Sele. In Vivere da Stranieri in Aree Fragili-L'immigrazione Internazionale Nei Comuni Rurali Italiani; Osti, G., Ventura, F., Eds.; Liguori: Napoli, Italy, 2012; pp. 89-104.

48. De Castro, C.; Gadea, E.; Pedreño, A.; Ramírez, A.J. Coaliciones sociales y políticas en el desarrollo del sector agroexportador: Las frutas murcianas y el trabajo en las redes globales de producción agroalimentaria. Mundo Agrar. 2017, 18, 1-20. [CrossRef]

49. Barciela López, C. Los Cambios En La Cadena Agroalimentaria Mundial En Las Últimas Décadas y La Posición de España. In El Sector Agroalimentario: Sostenibilidad, Cooperación y Expansión; Abadia Sánchez, R., Melgarejo Moreno, J., Eds.; Universidad de Alicante: Orihuela, Spain, 2017; pp. 23-50.

50. Langreo, A.; Germán, L. Transformaciones En El Sistema Alimentario y Cambios de Dieta En España Durante El Siglo XX. Hist. Agrar. 2018, 74, 167-200. [CrossRef] 